\title{
Oriental Religious Thoughts' Influence on Thoreau in Walden
}

\author{
Qin-Pei FAN
}

Shanghai Normal University Tianhua College, No. 1661 North Shengxin Road, Shanghai, China

39312543@qq.com

Key words: Oriental religious thoughts, Buddhism, Hinduism, Labor, Greed.

\begin{abstract}
Henry David Thoreau's contact with and research on the Oriental religions thoughts is closely related not only to the influence of his tutor Emerson, but also to his solitude and free life attitude which resists material pursuit to be the aim of life. Thoreau's thought and his works are greatly influenced by the Oriental religions thoughts, and Walden, as Thoreau's master piece, shines brilliantly. As a great writer, Thoreau maintains a pivotal position in American literary history with his unique thoughts in his works which enlightens the people of the world, and the Buddhist and Hinduist thoughts help form the uniqueness of Thoreau's thoughts.
\end{abstract}

\section{Introduction}

The influence of Oriental religion and culture can be found everywhere in the works of American writer Henry David Thoreau. In Thoreau's series of works like A week on Concord and Merrimack and Walden, his ideas are closely linked with Oriental religious ideas. The relationship between Thoreau and Oriental religious thoughts began with his mentor, Emerson. However, it was Thoreau that integrated Oriental religious ideas with transcendentalism and truly applies the essence of Oriental religious thoughts to real life. It is manifested in his critique of desire, critique of human being's conquering of nature, and his persistence in resisting all secular ways, maintaining his lonely and free life attitude, and returning to nature. This article will discuss the relationship between Thoreau and the Oriental religious thoughts through Thoreau's contact and study of Buddhism, as well as the statements in his work Walden.

\section{Thoreau's Contact and Research on Buddhism Originated from His Mentor, Emerson}

The central ideas of Emerson's philosophical system, such as Transcendentalism, are related to the teachings of the source of life in Hinduism. He read the translation version of the epic poems of Bhagavad-Gita, and in July 1842 he wrote a paper on Hinduism published on "The Dial". Meanwhile he had subscribed to the "Oriental scholar" series before 1850. Emerson discovered the "basic unity" of existence in Oriental religious literature such as the Bhagavad-Gita and the Vedas. He also discussed the "emptiness" thought in related papers. From his On Nature to The Over Soul, and then to his later thinking about illusion, Emerson's philosophy clearly has a strong Indian taste. Like Emerson, Thoreau also read Bhagavad-Gita and other India classics, and wrote a column on Hinduism and Buddhism on "The Dial". Thoreau later lived alone at Walden Pond for over two years, which was a kind of personal experimentation on mindfulness in Buddhism. He chose to put aside his life to indulge in the wonder and simplicity of the present moment. Therefore, the Oriental religious thoughts in Thoreau's works mainly refer to Buddhism and Hinduism.

\section{Thoreau's Oriental Religious Thoughts are Fully Reflected in Walden}

Walden is a true record of Thoreau's personal experience. In July 4, 1845, Thoreau moved to a forest near the beautiful Walden Pond not far away from his hometown Concord, and tried a simple life of seclusion. He set up a wooden house, opened up wasteland, wrote books, and lived a very simple and primitive life, self-sufficient for more than two years. He left Walden on September 6, 1847, “At present I am a sojourner in civilized life again.[1]". The collection of essays published in 
1854, Walden details the two years and two months of his life at Walden Pond. Although he graduated from Harvard University, he did not choose to make a fortune or become a star in politics. Instead, he chose the freedom and leisure of the soul.

In the first chapter "Economy", Thoreau describes slavery in this way: "What I have heard of Bramins sitting exposed to four fires and looking in the face of the sun; or hanging suspended, with their heads downward, over flames; or looking at the heavens over their shoulders...or dwelling, chained for life, at the foot of a tree; or measuring with their bodies, like caterpillars, the breadth of vast empires; or standing on one leg on the tops of pillars - even these forms of conscious penance are hardly more incredible and astonishing than the scenes which I daily witness. The twelve labors of Hercules were trifling in comparison with those which my neighbors have undertaken; for they were only twelve, and had an end; But I could never see that these men slew or captured and monster or finished any labor. [1] " Thoreau refers to the common sight that the people around him are occupied by the vacant grudge and vulgar work. In order to live more extravagant lives, people are struggling. "How many a poor immortal soul have I met well-nigh crushed and smothered under its load, creeping down the road of life, pushing before it a barn seventy-five feet by forty, its Augean stables never cleansed, and one hundred acres of land, tillage, mowing, pasture, and woodlot! The portionless, who struggle with no such unnecessary inherited encumbrances, find it labor enough to subdue and cultivate a few cubic feet of flesh. [1]" There is only one reason why people around us are engaged in hard labor for the rest of their lives: greed.

For greed, Bhagavad-Gita persuades us in this way: "If all kinds of desires are rejected, he will have peace and tranquility. This is Brahman. And Arjuna, when you reach that world, there is no darkness.[3]" Gaining happiness in materialistic enjoyment also breeds troubles and disasters. Greed is the source of all suffering. Possession is fleeting, and life and death are impermanent. Therefore, wise men will never indulge in greed.

Buddhism believes that life is suffering. And the cause of suffering is greed. Buddhism: Sutra on the Eight Realizations of the Great Beings says: "The second awareness: more desire will cause pain, life and death fatigue, which is aroused from greed; less desire or desire for nothing will lead to physical and mental freedom.[4]"

From a personal point of view, people should restrain their desires, not to expand and stimulate their desires. The reason why people always fall into pain is that they are always entangled with "annoyance". There are many kinds of annoyance, but three of them are main ones, the so-called "three poisoned" specifically referring to "greed", "deafness" and "insanity". The production of the "three poisoned" is related to the persistence of "I." For those things that are good for "I," they lust for it and pursue it, while they hate things that are not conducive to "I" or disagree with their own mind. The "three poisoned" are the root of all troubles. Eliminating the "three poisoned" means eliminating the troubles. This is to be "self-restraint". Control and overcome your greed for wealth, rights, status, reputation, etc.

From the social point of view, the most direct result of desire is that the pursuit of desire is too much emphasis on economic development and excessive consumption of natural resources and destruction of the natural environment. Recently, the problem of saving resources and protecting the environment has been recognized by all, and the way to fundamentally solve this problem is to reduce people's greed. Only greed is the driving force behind people's excessive demand from nature. If only greed declines, environmental protection is possible, and the respect for nature as well as the concept of unity between man and nature can be truly implemented.

How to restrain greed? "With respect to luxuries and comforts, the wisest have ever lived a more simple and meagre life than the poor. [1]" "Economy is a subject which admits of being treated with levity, but it cannot so be disposed of. [1]" If people can live in simplicity, there will not be so much anxiety to disturb the inner peace.

There is "Zen heart" in Buddhism, then, what is "Zen"? If we divide the word "Zen" into two parts, they are "showing" and "simple". The simple and straightforward expression of the heart is "Zen", and "Simple life" is also "Zen." At Walden Pond, Thoreau built a wooden house he thought comfortable and even warm with little raw material, where he used his hands to farm beans, fish, 
and bread. He believed that it was his very few needs that he could support himself with less labor. In the absence of a trace of desire, pure nature, he realized that the cause of suffering in the world is that the desire is too much, that the life is the pain, and the highest standard of life is simplicity, simplicity and simplicity.

Thoreau is such an enlightened person compared to his neighbors controlled by greed: "I would rather ride on earth in an ox cart, with a free circulation, than go to heaven in the fancy car of an excursion train and breathe a malaria all the way. [1]" The appetite for material and the greed for extravagant enjoyment come from ignorance. To abandon greed and become an enlightened person, we should establish the concepts of "nothingness" and "impermanence" and hold the heart of "kindness, grief, joy, and deportation" so that we can get rid of reincarnation, enter infinity, and attain nirvana.

At Walden Pond, Thoreau cultivates, contemplates, reads, writes, simplifies life, deepens life, cherishes life, enjoys inner ease and enjoyment, and truly finds the direction and meaning of life.

\section{Conclusion}

Buddha is an enlightened and also an enlightening person. In other words, Buddha is one who has already had a thorough understanding of the fundamental principles of the universe and life, and further helps other people to be able to realize it. Dharma is different from other religions: Buddha is not omnipotent, and Buddha cannot give relief to the world. He can only teach the world, and the world must be relieved by his own efforts. To some extent, Thoreau is exactly what Buddhism has called a well-informed person, and "Walden" is a great work that guides modern people to be enlightened.

\section{References}

[1]. Henry David Thoreau, Walden, Foreign Language Press, 2008, pp. 5, 6, 7,16,31,38

[2]. Zhankui Liu, Comments on “Bhagavad-Gita” , Social Sciences Documentation Press, 2010

[3]. Vyasa, Baosheng Huang (trans), Bhagavad-Gita, The Commercial Press, 2010, pp.93

[4]. http://page.renren.com/601103566/note/886058554 